\title{
Strategic Use of Government Procurement to Spur Renewable Energy Generation in Malaysia
}

\author{
KHAIRUL NAIM ADHAM ${ }^{1 *}$, CHAMHURI SIWAR ${ }^{1}$, \\ SARAH AZIZ ABD GHANI AZIZ and MD. ANOWAR HOSSAIN BHUIYAN'
}

'Institute for Environment and Development (LESTARI), National University of Malaysia (UKM), 43600 Bangi Selangor, Malaysia.

http://dx.doi.org/10.12944/CWE.9.2.04

(Received: May 07, 2014; Accepted: July 13, 2014)

\begin{abstract}
The energy sector plays an important role in Malaysia's socioeconomic development. However energy production is the largest contributor to air pollution. Malaysia's emission intensity levels of green house gases (GHGs) in the energy sector are above the global average. In this view, government procurement which refers to the acquisition of supplies, services and works by the government plays a vital role as an economic instrument to promote sustainable use of energy - by intensifying the development of renewable energy (RE) and encourage energy efficiency practices. These would ensure continuous supply of energy for future generation, and reduce the negative impact to human and environment. In the context of Malaysia, its huge public expenditure of 24-33\% of Gross Domestic Product (GDP) could be used to spur RE generation by integrating RE requirements in constructing or upgrading government buildings. By having this initiative, the government will show its strong commitment towards promoting RE generation and creating a favourable environment for RE development.
\end{abstract}

Key words: Government procurement, Government green procurement, Sustainable energy, Renewable energy, Energy efficiency.

\section{INTRODUCTION}

Energy sector is the backbone of Malaysia's economic development striving for high income developed nation, inclusiveness and sustainability by 2020 (KeTTHA 2009; MNRE, 2009; NEAC, 2010a; 2010b). Energy is an essential element for social and economic growth (Haw et al., 2006) and economic competitiveness requires sustainable energy production and consumption (MNRE, 2010). Malaysia's Green Technology Policy has recognised energy sector as one of the four pillars in accelerating the Malaysia's economic development (KeTTHA, 2010). However, rapid economic development has drastically increased the country's energy consumption and subsequently contributing to environmental degradation. According to EU (2011), electricity generation from fossil fuels is one of the principal sources of green house gases (GHGs) emissions globally. Available evidences have shown energy production is the largest contributor toair pollution in Malaysia (KeTTHA, 2009). Moreover, Malaysia's GHGs emission intensity levels in the energy sector are above the global average (UNDP, 2009). According to the Second National Communication to the United Nation Framework Convention on Climate Change, energy industries in Malaysia are the largest carbon dioxide $\left(\mathrm{CO}_{2}\right)$ emitters amounting to $35 \%$ of the total $\mathrm{CO}_{2}$ emission (MNRE, 2009). This shows energy sustainability is vital to deal with the growing pressure on environment. For these reasons, sustainable energy development measures have become one of the Malaysian government strategies towards ensuring its vibrant and sustainable economic growth.

In recognising the importance of energy sustainability, the Malaysian government has taken various measures to ensure long term reliability and security of energy supply, efficient utilization 
of energy and at the same time reducing the negative impact on the environment. In the context of Malaysia, SEDA (2011a) defines sustainable energy as an energy which in its generation, provision and use has minimal negatives impact to human and environment, and can be supplied continuously to future generation. One of the approaches in achieving sustainable energy is by promoting the use of renewable energy (RE). RE refers to any form of primary energy from recurring and non-depleting resources (KeTTHA, 2009) or energy derived from natural processes that are constantly replenished (MNRE, 2010). According to EU Directive 2009/28/EC on the promotion of the use of energy from renewable sources, RE sources are renewable non-fossil energy sources including wind, solar, geothermal, wave, tidal, hydro-power, biomass, landfill gas, sewage treatment plant gas and biogases (EC, 2004).

The use of RE is expected to reduce the environmental pollution due to the GHGs emissions such as $\mathrm{CO}_{2}$, nitrogen oxides $\left(\mathrm{NO}_{x}\right)$, sulphur oxides $\left(\mathrm{SO}_{\mathrm{x}}\right)$ and particulate matters as a result of power generation from oil, natural gas and coal (Mustapa et al., 2010; KeTTHA, 2011). RE resources in Malaysia include palm oil biomass wastes such as empty fruit bunches (EFB), mesocarp fibres, palm kernel shells (PKS) and palm oil mill effluents (POME); mini-hydro; solar power; solid waste and land-fill gas; wind energy and geothermal; wastes and gases from agro-based and farming industries (KeTTHA, 2009). Malaysia aims to achieve RE target of $985 \mathrm{MW}$ (contributing $5.5 \%$ to Malaysia's total electricity generation mix) by 2015 (KeTTHA, 2009) and 2,080MW (11\%) by 2020 (KeTTHA 2009).In achieving sustainable energy, the Malaysian government has made efforts to intensify the development of RE and encourage energy efficiency practices. However, the paper focuses only on the development of RE. The paper highlights how government procurement could be used as one of the instruments towards promoting RE generation.

\section{MATERIALS AND METHODS}

\section{Methods}

The study is review in nature. The study used secondary sources such as policies and plans from relevant ministries and agencies of the Malaysian Government. The published document were reviewed in order to obtain an overview of RE initiatives in Malaysia.

\section{Government green procurement (GGP)}

Government procurement refers to the acquisition of supplies, services and works in accordance with government rules and regulations (Adham\&Siwar, 2012b). Government procurement plays a crucial role for socioeconomic development in Malaysia as it represents 24-33 percent of gross domestic product (GDP) (Adham\&Siwar, 2011). In dealing with environmental degradation issues, government procurement could also be used to minimize the impact to the environment or known as government green procurement (GGP). Bouwer et al. (2005) have defined GGP as the approach by which Public Authorities integrate environmental criteria into all stages of their procurement process, thus encouraging the spread of environmental technologies and the development of environmentally sound products, by seeking and choosing outcomes and solutions that have the least possible impact on the environment throughout their whole life-cycle. GGP among others includes purchasing of energy-efficient computers, office equipment made from sustainable timber, recycled paper, hybrid or low-emission vehicles and constructing green/low energy buildings (EC, 2004; EU, 2011). According to Geng\&Doberstein (2008), the effective implementation of GGP could offer greater impacts for the developing countries where many of them are facing natural resource scarcities. Benefits associated with the implementation of GGP are not only limited to environment but also on the economic and social aspects. Empirical studies have found that GGP has the potential to reduce $\mathrm{CO}_{2}$ emissions and operating costs by the government in the long run (PWC et al., 2009; EC, 2004). EU found that if all public authorities across the EU demanded for green electricity, it will save about 60 million tons of $\mathrm{CO}_{2}$ which is equivalent to $18 \%$ of the EU's greenhouse gas reduction commitment under the Kyoto Protocol (EC, 2004). GGP practices have been implemented in many countries throughout the world and have been regarded as an effective means of reducing environmental burdens. For this reason, more and more countries have established GGP policies at national levels to integrate environmental considerations in their government procurement decisions. In the context of Malaysia, GGP is 
defined as the acquisition of products, services and work in the public sector that takes into account environmental criteria and standards to conserve the natural environment and resources, that minimises and reduces the negative impacts of human activities (KeTTHA, 2012). Environmental criteria in the given definition refer to products, equipment or systems that minimize degradation to the environment, have zero or low green house gas (GHG) emission, safe for use and promote healthy and improved environment for all forms of life, conserve the use of energy and natural resources, and promote the use of renewable resources such as RE as outlined in the NGTP (KeTTHA, 2009).

\section{Sustainable energy}

The importance of energy sustainability in Malaysia had been recognised many years ago. Initial efforts towards achieving energy sustainability have been initiated since 1975 when the National Petroleum Policy (NPP) was introduced to ensure optimal use of petroleum resource. Four years later, the National Energy Policy (NEP) was formulated with three primary objectives which are to ensure the provision of adequate energy supplies, efficient utilization of energy and minimization of environmental burden. In achieving these objectives, subsequent energy policies such as the National Depletion Policy (NDP; 1980) and Four-Fuel Diversification Policy (4FDP; 1981) were formulated. NDP is intended to conserve Malaysia's energy resources particularly oil and gas whereas 4FDP aims to reduce Malaysia's overdependence on oil as the energy source (Hitam, 2000).

\section{DISCUSSION}

The Malaysian government has introduced several initiatives to support the development of RE such as the implementation of photovoltaic (PV) System for Rural Electrification Program, Small Renewable Energy Programme (SREP), Biomass Power Generation and Demonstration Project (BioGEN) and Malaysian Building Integrated Photovoltaic Technology Application Project (MBPIV) (MNRE, 2009). Besides that, fiscal incentives such as the Pioneer Status (PS) or Investment Tax Allowance (ITA), have also been introduced (KeTTHA, 2009).

\section{Renewable energy initiative in Malaysia}

In recognising the potential of $\mathrm{RE}$, the Malaysian government has embarked on a number of initiatives to encourage the use of $R E$ as an additional source of fuel as outlined in the FiveFuel Diversification Policy (5FDP; 2001) under the $8^{\text {th }}$ Malaysia Plan (8MP; 2001-2005) (EPU, 2001). Besides oil, gas, hydro and coal, 5FDP has identified additional sources of energy from biomass, biogas, municipal waste, solar, wind and mini-hydro for electricity generation. Efforts to develop and promote the utilization of $R E$ were further intensified under the $9^{\text {th }}$ Malaysia Plan (9MP; 2006-2010) (EPU, 2006).

The use of PV systems (solar generating sets and solar hybrids) for rural electrification has been initiated way back in 1980s for rural villages without electricity supply. SREP was launched in 2000 to intensify the utilization of RE in power generation with RE targeted to contribute $5 \%$ of generation capacity by 2005 . Five RE sources have been identified under SREP which are biomass, biogas, solar, mini-hydro and solid waste. SREP allows renewable energy projects of up to $30 \mathrm{MW}$ in capacity to sell output to the utility company (Adham et al., 2013). BioGEN aims at developing and exploiting energy potentials of biomass from palm oil industries while MBIPV attempts to act as a catalyst for greater Building Integrated Photovoltaic (BPIV) technology acceptance among the public and private sector. MBIPV focuses on three major areas namely policy and education, technical skill and market implementation and technology development support to increase BPIV applications and induce long term cost reduction (KeTTHA, 2009).

The use of biofuel has been identified as one of the strategies to reduce dependency on fossil fuels. In this regard, the Malaysian government has set the platform for the development of the biofuel industry in Malaysia with the release of the National Biofuel Policy (NBP) on March 2006. The policy is primarily aimed at reducing the country's dependence on depleting fossil fuels, promoting the demand for palm oil as well as stabilizing its prices at a remunerative level. NBP envisions use of environmentally friendly, sustainable and viable sources of energy to reduce the dependency on depleting fossil fuels; and enhance prosperity and 
well-being of all the stakeholders in the agriculture and commodity based industries through stable and remunerative prices. Five strategic thrusts are underpinned NBP viz. biofuel for transport; biofuel for industry; biofuel technologies; biofuel for export; and biofuel for cleaner environment. NBP encourages the use of biofuel by providing incentive for biofuel infrastructure development and developing industry standards (MPIC, 2006).

The National Green Technology Policy (NGTP) was launched in 2009 to promote the use of green technology in accelerating the Malaysia's economy and promote sustainable development. NGTP has clearly stated Malaysia intentions to promote the use of renewable resources and attaining energy independence (KeTTHA, 2010). The National Policy on Climate Change (NPCC) was formulated in 2010 to encourage wise management of natural resources and enhance environmental conservation as a measure to strengthen economic competitiveness and improve the people's quality of life (MNRE, 2010). NPCC in its strategic thrust aims at enhancing RE. The National RE Policy and Action Plan (NREPAP) was launched on April 2010 to enhance the utilization of indigenous RE resources to contribute towards national electricity supply security and sustainable socio-economic development. It has five key objectives namely (i) to increase RE contribution in the national power generation mix; (ii) to facilitate the growth of the RE industry; (iii) to ensure reasonable RE generation costs; (iv) to conserve the environment for future generation; and $(v)$ to enhance awareness on the role and importance of RE. In order to achieve the policy objectives, 5 strategic thrusts have been drawn namely (i) introduction of appropriate regulatory framework such as RE Act and Feedin-tariff (FiT) mechanism; (ii) providing conducive environments for RE businesses such as the provision of fiscal incentives; (iii) intensifying human capital development; (iv) enhancing RE research and development; and ( $v$ ) designing and implementing RE advocacy programme. NREAP aims to produce $985 \mathrm{MW}(6 \%)$ of RE in the year 2015 and $21.4 \mathrm{GW}$ (73\%) by 2050 (KeTTHA, 2009). The Malaysia's RE Policy and Action Plan has highlighted a number of RE resources in Malaysia and their potentials as shown in Table 1.
The $10^{\text {th }}$ Malaysia Plan (10MP; 2011 . 2016) indicates the Malaysian Government path in advancing RE. The 10M Precognizes the importance of $R E$ as one of the new growth areas to ensure reliable, high quality and cost-effective supply of energy. Among other measures to secure and manage reliable energy supply are by enhancing the use of alternative resources (particularly hydro), regulating the use of biofuel in the transport sector, developing new-coal based plants and applying critical coal technology. For these reasons, besides ensuring reliability of electricity supply, the 10MP emphasizes in creating demand for RE to spur business opportunities. In achieving the goals, three main strategies have been outlined namely (i) developing and enforcing regulations especially on energy efficiency in buildings for new developments; (ii) promoting investment in $\mathrm{RE}$ to provide long-term contracts for RE providers and create the spill over effects on the related domestic service providers; and (iii) promoting culture of conservation and efficiency in energy and water use. The 10MP is aiming at increasing RE contributions to $5.5 \%$ of Malaysia's total electricity generated by 2015 (EPU, 2010).

The Government Transformation Program (GTP) draws the need of using creative and innovative solution such as implementing solar hybrid power generation or micro hydro-electricity as a catalyst for the development of sustainable energy in Malaysia (PEMANDU, 2010a). The New Economic Model (NEM) under its Strategic Reformation Initiatives 8 (SRI8) targets to preserve natural environment by formulating comprehensive energy policy as a push factor to shift to RE (NEAC, 2010a; 2010b). Under the Economic Transformation Program (ETP), the Malaysian government has identified four entry point projects (EPPs) as a platform to promote sustainable energy development namely improving energy efficiency (EPP9); building up solar power capacity (EPP10); developing nuclear energy for power generation (EPP12); and tapping Malaysia's hydroelectricity potential (EPP12). EPP10 intends to increase solar power capacity of at least $220 \mathrm{MW}$ by 2020 while EPP12 realizes the potential of hydroelectricity in providing a secure and long term supply of electricity particularly in Sarawak and Borneo region (PEMANDU, 2010b). 
Table 1: RE resources potential in Malaysia

\begin{tabular}{lc}
\hline RE Resources & Potential (MW) \\
\hline Biomass & 1.340 \\
Biogas & 410 \\
Mini Hydro & 500 \\
Solar PV & 6,500 \\
Municipal Waste & 400 \\
Total & 9,150 \\
\hline
\end{tabular}

Source: KeTTHA (2009)
In order to provide a more favourable environment for RE development, the Renewable Energy Act (REA; 2011) and Sustainable Energy Development Authority Act 2011 (SEDAA; 2011) have been enacted under the 10MP. REA is an act to facilitate sustainable RE growth and development. REA provides a special tariff system to stimulate the generation of RE and outlines provision for Feed-in Tariff (FiT) mechanism's implementation. The FiT is a mechanism that allows electricity produced from indigenous RE resources to be sold to power utilities at a fixed premium price for a specific duration (KeTTHA, 2011; SEDA, 2011b). REA is

Table. 2: RE initiatives in Malaysia

\begin{tabular}{ll}
\hline Year & Initiatives \\
\hline 1980 s & Photo Voltaic (PV) System for Rural Electrification Program \\
1998 & First PV Grid Connected System Application \\
2001 & Formulation of Fifth Fuel PolicySmall RE Power Program (SREP) \\
2002 & Biomass Power Generation and Co-Generation Project (BIOGEN) \\
2005 & Malaysia Building Integrated Photovoltaic Project (MBIPV) \\
2006 & National Biofuel Policy \\
2009 & National Green Technology Policy (NGTP) \\
2010 & National RE Policy and Action Plan (NREPAP) \\
2011 & Renewable Energy Act (REA) Sustainable Energy Development Authority Act 2011 (SEDAA)
\end{tabular}

Source: Adapted MNRE (2009)

Table. 3: RE implementation issues

\begin{tabular}{ll}
\hline Issues & Description \\
\hline Market failure exists & $\begin{array}{l}\text { The RE market "fails" due to misuse of monopsony power and } \\
\text { information asymmetries; the RE market is also constrained by } \\
\text { financial and technological factors }\end{array}$ \\
Inherent factor & RE prices set arbitrarily \\
Arbitrary price setting & The predicament of expecting that the utility will bear the higher costs \\
Tensions and trade-offs & of RE power (due to the higher RE price) \\
Absence of Regulatory & Market failure compounded by absence of a proper regulatory \\
Framework & framework, which prevents proper and legal action from being taken \\
Poor governance & Poor governance detrimentally affects the participation of stakeholders \\
& and legitimacy of the action \\
Limited Oversight & No concerted oversight of implementation problems \\
Lack of institutional & Lack of proper institutional measures to meet informational and \\
measures & technological needs
\end{tabular}

Source: KeTTHA (2009) 
Table. 4: Malaysian government commitments towards GGP

Documents Commitments

10MP There will be a push towards green technology through the National Green Technology Policy, in preparation for green products and services becoming the preferred choice for public procurement (p. 83)

KeTTHA together with SIRIM Berhad, will develop a national eco-labeling scheme and standards for our products and services that match international standards. This will in turn support the government's green procurement initiative as well as assist local manufacturers to export their products. Increased labeling of environmentally friendly goods and services such as Energy Efficiency Star Rating, Low Carbon Footprint Products and Green Building Index will increase Malaysia's competitiveness (p. 299) Implementing value-management analysis and life-cycle cost evaluation for procurement. Development programmes and projects costing RM50 million or more will be subject to value-management analysis. This approach requires consideration of various options to arrive at the optimal project design aligned to the desired outcomes. Life-cycle cost evaluation will ensure cost optimization and value-for-money while meeting required performance levels. Ministries and agencies implementing projects costing less than RM50 million will also be encouraged to conduct similar analyses (p.338)

NEM Ensure public procurement supports local innovation (p.28) A more efficient procurement process will address wider issues covering long-term economic and social viability, environmental impact, and the residual contingency risks that government may have to bear (p. 93)

ETP Boost demand for green products and services. Government will take the lead in raising efficiency and growing the green technology industry. First, the KeTTHA will set efficiency targets stipulating that all ministries must reduce electricity and water consumption by 10 percent per year from 2011 to 2013 . Second, KeTTHA will set the target across ministries that 50 percent of the goods and services purchased by the public sector should be eco-labeled by 2020. To this end, a green public procurement policy shall be put in place by October 2011, to give preference to local producers, establish buying guidelines for eco-labeled products and specify the required energy efficiency certification for specific products ( $p .417$ )

NGTP Short-term goals: $10^{\text {th }}$ Malaysia Plan (ii) widespread availability and recognition of Green Technology in terms of products, appliances, equipment and systems in the local market through standards, rating and labeling programs, (p. 7).

Mid-term goals: $11^{\text {th }}$ Malaysia Plan (i) Green technology becomes the preferred choice in procurement of products and services, (ii) Green Technology has a larger local market share against other technologies, and contributes to the adoption of Green Technology in regional market, (ii) Increased production of local Green Technology products (p. 10) Long-term goals: $12^{\text {th }}$ Malaysia Plan and beyond (ii) Widespread adoption of Green Technology reduces overall resource consumption while sustaining national economic growth, (v) Malaysia becomes a major producer of Green Technology in the global market (p. 10)

NREPAP Government should use its strategic public procurement power to spur RE regeneration and industry growth (p.57)

SMEMP In many countries, government have played a major role in supporting SME product through specific government procurement policy (p.100)

Annual 2010 - give priority to environmentally-friendly products and services that comply with Federal green technology standards in government procurement (p. 19)

Government

Budget 
also allows the establishment of Sustainable Energy Development Authority (SEDA) as an implementing agency for FiT. SEDA is tasked to manage the RE Fund to ensure RE becomes a viable and sound long-term investment for companies, industries and individuals (SEDA, 2011b). RE initiatives in Malaysia are summarized in Table 2.

\section{Issues and challenges for RE development in Malaysia}

Prior to NREPAP, the development of RE in Malaysia has been generally slow due to a number of issues and challenges in Table 3. Despite a range of RE's initiatives and incentives, the RE target set out under 8MP and 9MP was not achieved (EPU, 2010). For instance, the BioGEN was unable to achieve its intended objectives due to inability to control certain parameters (MNRE, 2009). The Government has set a target of $300 \mathrm{MW}$ of the country's electricity from RE by 2010, but only achieved up to $56.7 \mathrm{MW}$ (KeTTHA 2009). Presently, RE development has shown good progress but its development is still considered slow. As of December 2013, SEDA has approved RE projects with RE capacity of $482 \mathrm{MW}$, comprising solar PV (40.2\%), biomass $(27.2 \%)$, hydropower (27.2\%) and biogas (4.9\%) (SEDA, 2013). Based on this trend, the authors find PV has shown good progress while the developments of other RE sources are under-performed. If this trend continues, it will be difficult to meet Malaysia's goal of producing $985 \mathrm{MW}$ of RE by the end of 2015 . The issues and challenges need to be addressed wisely to ensure the RE targets could be achieved.

\section{Government green procurement in malaysia}

GGP is still a new concept in Malaysia (Adham\&Siwar, 2011; 2012a; 2012b). At this point in time, GGP has not been formally adopted and there is no policy, regulation and legal framework with regards to GGP (Adham\&Siwar, 2011; 2012a; $2012 b$ ). While Malaysia is somewhat behind the line in term of GGP implementation, as compared to its neighbouring countries, the Malaysian government has acknowledged the importance of GGP and initial steps have been taken towards its implementation. The Malaysian government commitments have been outlined in 10MP, NEM, ETP, NGTP, NREPAP, Small and Medium Enterprises Master Plan (SMEMP) and Annual Federal Government Budget. Under the ETP, the Government has made GGP as one of its Entry
Point Projects (EPP). Table 4 shows details of the Malaysian government commitments.

\section{Strategic use of GGP}

GGP could be considered as enabling factors that would promote the generation of RE. One of the GGP approaches is by giving preferences to designs which incorporate RE systems or require electricity (or a proportion of electricity) to be generated from renewable energy sources (EC, 2004; EU, 2011). Electricity produced from renewable energy sources refers to electricity produced by plants using only renewable energy sources as well as the proportion of electricity produced from renewable energy sources in hybrid plants also using conventional energy sources (EU, 2011). In this aspect, many EU's public authorities are now procuring electricity from RE sources. Some related examples can be seen in the construction of school in Pembroke, Malta and hospital in Vienna, Austria. The use of on-site RE production is required in constructing new school buildings in Pembroke whilst the use of RE sources is one of the requirements in constructing new hospital in Vienna.

Likewise, government procurement in Malaysia could also be used strategically to spur RE generation. This approach is in line with NREPAP where NREPAP suggests government to include the use of building integrated $R E$ as a requirement in upgrading its federal buildings (KeTTHA, 2009). To achieve this, design elements for RE technology in particular BIPV, could be incorporated into the Malaysia's government standard and cost guidelines and procedures. The preference to $\mathrm{RE}, \mathrm{RE}$ technologies and the requirement for building integrated RE could also demonstrate the government's commitment to RE, create demand for RE materials and enhance RE skills which in turn will encourage market entry of related businesses (KeTTHA, 2009).

\section{CONCLUSION}

Energy sustainability contributes greatly to Malaysia's agenda to become high-income developed nation, sustainable and inclusive in the year 2020. Since time of abundant and low-priced resources that the people enjoyed in the past decade is coming to a full stop, the use of RE is one of 
the approaches in dealing with this situation. The implementation of GGP could serve as one of the solutions by utilizing the huge government spending as a market force to spur RE generation. In long term, widespread RE generation would ensure reliability and security of energy supply, reduce GHGs emission and enhance the people's quality of life.

\section{ACKNOWLEDGMENTS}

The authors would like to acknowledge the Ministry of Education of Malaysia and National
University of Malaysia for providing Fundamental Research Grant Scheme (FRGS) on 'Greening the Economy' (FRGS/1/2012/SSO7/UKM/01/3) and Exploratory Research Grant Scheme (ERGS) on 'The measurement of Oil Palm Economic Potential' (ERGS/1/2013/SS07/UKM/01/1) which made this study possible. Both grants are headed by Emeritus Professor ChamhuriSiwar. Sincere gratitude also to Public Service Department of Malaysia for providing the scholarship under Federal Training Award Scheme to the first author.

\section{REFERENCES}

1. Adham, K.N. and Siwar, C., Perolehan produk hijau di sektor awam Malaysia: halatuju, inisiatif dan prospek, Jurnal Pengurusan Awam 8(1), 61-90 (2011), (in Malay).

2. Adham, K.N. and Siwar, C., An empirical investigation of government green procurement (GGP) practices in Malaysia, OIDA International Journal of Sustainable Development 4(4), 77-87 (2012a)

3. Adham, K.N. and Siwar, C., Transformation of government procurement in Malaysia: direction and initiatives, Proceeding of the $5^{\text {th }}$ International Public Procurement Conference 2012 (IPPC 2012), 17-19 August 2012, Sheraton Seattle Hotel, USA, Part VII Reforms and Transformation of Governance, 1620-1641. (2012b).

4. Adham, K.N., Merle, K. and Weihs, G, Sustainable Consumption and Production Policy Support for Malaysia: A Baseline Study on Government Policies, Institutions and Practices, Economic Planning Unit, Prime Minister's Department Malaysia, Putrajaya (2013)

5. Bouwer, M., de Jong, K., Jonk, M., Berman, T., Bersani, R., Lusser, H., Nissinen, A., Parikka, K. andSzuppinger, P., Green public procurement in Europe 2005 - status overview, The Netherlands: Virage Milieu \& Management bv, KorteSpaarne 31: 2011 AJ Haarlem (2005)

6. European Commission (EC), Buying Green! - A Handbook on environmental public
procurement,Luxembourg: Office for Official Publications of the European Communities (2004)

7. Economic Planning Unit Malaysia (EPU), $10^{\text {th }}$ Malaysia Plan 2011-2015, Economic Planning Unit, Prime Minister Department, Kuala Lumpur: Percetakan Nasional Malaysia Berhad (2010)

8. Economic Planning Unit Malaysia (EPU), $8^{\text {th }}$ Malaysia Plan 2001-2005, Economic Planning Unit, Prime Minister Department, Kuala Lumpur: Percetakan Nasional Malaysia Berhad (2001)

9. Economic Planning Unit Malaysia (EPU), $9^{\text {th }}$ Malaysia Plan 2006-2010, Economic Planning Unit, Prime Minister Department, Kuala Lumpur: Percetakan Nasional Malaysia Berhad (2006)

10. European Union (EU), Buying Green! - A Handbook on environmental public procurement 2nd Edition,Luxembourg, Publications Office of the European Union(2011).

11. Geng, Y. and Doberstein, B., Greening government procurement in developing countries: Building capacity in China, Journal of Environmental Management, 88: 932-938 (2008)

12. Haw, L.C., Salleh, E. and Jones, P., Renewable energy policy and initiatives in Malaysia, ALAM CIPTA International Journal on Sustainable Tropical Design Research and Practice, 1(1), 33-40 (2006) 
13. Hitam, S., Sustainable energy policy and strategies: A pre-requisite for the concerted development and promotion of the renewable energy in Malaysia, Economic Planning Unit Kuala Lumpur (2000).

14. Ministry of Energy, Green Technology and Water (KeTTHA),National Renewable Energy Policy and Action Plan,Ministry of Energy, Green Technology and Water Malaysia, Putrajaya (2009)

15. Ministry of Energy, Green Technology and Water Malaysia (KeTTHA). National Green Technology Policy,Ministry of Energy, Green Technology and Water Malaysia, Putrajaya (2010)

16. Ministry of Energy, Green Technology and Water (KeTTHA),Handbook on the Malaysian Feed-in Tariff for the promotion of renewable energy,Ministry of Energy, Green Technology and Water, Putrajaya (2011)

17. Ministry of Energy, Green Technology and Water (KeTTHA), Pengenalan Perolehan HijauKerajaan Edisi 1,KeTTHA,Putrajaya (2012) (in Malay)

18. Ministry of Finance Malaysia (MOF), The 2010 Budget Speech, Ministry of Finance Malaysia, Putrajaya,Percetakan Nasional Malaysia Berhad(2009a)

19. Ministry of Natural Resources and Environment Malaysia (MNRE), National Policy on Climate Change, Ministry of Natural Resources and Environment Malaysia, Putrajaya (2010)

20. Ministry of Natural Resources and Environment Malaysia (MNRE), Malaysia Second National Communication to the UNFCCC, Ministry of Natural Resources and Environment Malaysia, Putrajaya (2009)

21. Ministry of Plantation Industries and Commodities (MPIC), National Biofuel Policy,Ministry of Plantation Industries and Commodities, Putrajaya (2006).

22. Mustapa, S.I., Peng, L.Y. and Hashim, A.H., Issues and challenges of renewable energy development: A Malaysian experience, RERIC Asian Institute of Technology, The Empress Hotel, Chiang Mai, Thailand, 2-4 June (2010)

23. National Economic Advisory Council Malaysia (NEAC), New economic model for Malaysia Part 1,Percetakan Nasional Malaysia Berhad,
Kuala Lumpur (2010a)

24. National Economic Advisory Council Malaysia (NEAC), New economic model for Malaysia Concluding Part, Percetakan Nasional Malaysia Berhad, Kuala Lumpur (2010b)

25. Performance Management and Management Unit (PEMANDU), Government Transformation Program, Performance Management and Management Unit, Prime Minister Department,Percetakan Nasional Malaysia Berhad, Kuala Lumpur (2010a)

26. Performance Management and Management Unit (PEMANDU), Economic Transformation Program, Performance Management and Management Unit, Prime Minister Department,Percetakan Nasional Malaysia Berhad, Kuala Lumpur (2010b)

27. PricewaterhouseCoopers (PWC), Significant and Ecofys, Collection of statistical. information on Green Public Procurement in the EU - Report on data collection results,PricewaterhouseCoopers, Significant andEcofys (2009) http://www. ec.europa.eu/ environment/gpp/pdf/statistical_information. pdf [12 Jun 2013]

28. SME Corporation Malaysia (SME), SME Masterplan, SME Corporation Malaysia, Kuala Lumpur (2012)

29. Sustainable Energy Development Authority (SEDA),Sustainable Energy Development Authority Act 2011 (2011a) http:// seda.gov.my/gohome.php?omaneg = 0001010000000101010100010000100 $0000000000000000000 \& s=147$ [accessed on 29 December 2011]

30. Sustainable Energy Development Authority (SEDA), Overview of the FiT System in Malaysia, (2011b) http://seda.gov.my/gohome.php?omaneg $=0001010000000101$ 0101000100001000000000000000000000 $\& s=6$ [accessed on 29 December 2011].

31. Sustainable Energy Development Authority (SEDA), RE generation (2013). http://seda. gov.my

32. United Nations Development Programme (UNDP), Human Development Report 2007/2008, Fighting Climate Change: Human Solidarity in a Divided World, Palgrave Macmillan, New York (2009) 